Contents list available at IJRED website

Int. Journal of Renewable Energy Development (IJRED)

Journal homepage: http://ejournal.undip.ac.id/index.php/ijred

\title{
Soybean Opportunity as Source of New Energy in Indonesia
}

\author{
M. Muchlish Adie*, and Ayda Krisnawati
}

Indonesian Legumes and Tuber Crops Research Institutes, PO Box 66, Malang, INDONESIA

\begin{abstract}
These last few years, the name of soybeans soared as a source of biodiesel. Soy biodiesel is an alternative fuel produced from soybean oil. Soybean potential as an alternative renewable energy source because it is expected to have the highest energy content compared to other alternative fuels. Opportunities to develop biodiesel using soybean oil in Indonesia is quite large, considering the soybean is a commodity that is already known and widely cultivated almost in all over Indonesia. In addition, the use of soybean for biofuel feedstock is expected to motivate farmers to cultivate soybeans, so their use is not limited to non-energy raw materials. Soybean varieties that have a high oil content as well as high yield is a source of major biodiesel feedstock. From 73 soybean varieties that have been released in Indonesia, has an average oil content of $18 \%$. Varieties with high oil content can be used as raw material for biodiesel. Research on the use of soy as an ingredient of energy crops (biodiesel) have been carried out. In fact, soybean oil is the vegetable oil feedstock for most of the biodiesel being produced in the United States today. With the potential for soybean crops in Indonesia, both in terms of availability of land and varieties, the use of soybean oil for biofuel development in Indonesia is the flagship prospective materials for bio fuel substitute than other plants in the future.
\end{abstract}

Keywords: biodiesel, new energy, soybean

Article History: Received September 26, 2013; Received in revised form December 12, 2013; Accepted February 1, 2014; Available online

How to Cite This Article: Adie, M.M \& Krisnawati, A. (2014) Soybean Opportunity as Source of New Energy in Indonesia. Int. Journal of Renewable Energy Development, 3(1), 37-43.

http://dx.doi.org/10.14710/ijred.3.1.37-43

\section{Introduction}

Recently, biofuels has been popular as a new energy resources. These so-called "energy crops" include wheat, corn, soybeans and sugarcane. Biofuels is a fuels made from plants, as a way to decrease the world's consumption of fossil fuels, especially oil. Biodiesel is a clean and renewable fuel which is considered to be the best substitution for diesel fuel (Singh \& Singh 2010).

Indonesia has no less than 60 oil-producing plant species that can be processed into fuel oil, one of which is a soybean biofuel crops. Soybean is a commodity that is already known and widely cultivated almost in all over Indonesia. Soybean has a high content of nutrients, especially protein which reached 34 percent of that is in high demand as a source of relatively inexpensive vegetable protein than animal protein (Ditjentan 2004). As a source of vegetable protein, soybean is generally consumed in the form of processed products, ie: tofu, tempeh, soy sauce, tauco, soy milk, and various forms of snacks (Sudaryanto \& Swastika 2007). Soybeans are not only used as a source of vegetable protein, but also as a functional food to prevent degenerative diseases, such as coronary heart disease and hypertension. Substance isoflavones contained in soy apparently function as antioxidants. Not only that, this time soybean is widely used as an alternative energy source (biofuel).

Nowadays, soybean becomes strategic commodity due to the volume of demand and a large and diverse usage. Indonesia's largest soybean acreage is planted in the wetland area in July-October following a year cropping pattern of rice - rice - soybean (Adie 2008). The knowledge and use of soybean growing has a great importance for the development of certain regions in Indonesia, especially upland acid soil and tidal swamp land scattered outside Java.

The agricultural sector now faces new challenges of the global energy crisis issue. The fact that petroleum as

\footnotetext{
* Corresponding author: Tel: +62-81333220026

E-mail:mm_adie@yahoo.com
} 
Citation: Adie, M.M \& Krisnawati, A. (2014) Soybean Opportunity as Source of New Energy in Indonesia. Int. Journal of Renewable Energy Development, 3(1), 37-43 doi: 10.14710/ijred.3.1.37-43

$\mathrm{P}$ a g e $\mid \mathbf{3 8}$

a source of energy derived from fossil and widely used by humans it will eventually run out has prompted the search for alternative energy sources instead of petroleum. This makes the trend of biofuel as an alternative energy source derived from plants become popular.

Development of soybean as a new energy source (biofuel) in Indonesia is very promising. Biodiesel feedstock such as jatropha, soybean, and palm oil are plants that are found in Indonesia, but not all of these plants are cultivated extensively. Soybean is a plant that has been cultivated widely in almost all Indonesian, so as to meet the raw material needs urgent biodiesel, the plants should receive primary attention. A total of 73 soybean varieties that have been released, and some of them have the opportunity to be used as raw material for biodiesel. Currently, soybeans mostly used for nonenergy purposes, so the development of soybean for biofuel feedstock is a challenge and expected to require land development and further research.

The objective of this review paper is to identify the soybean prospects as source of new energy and discuss the opportunity for to be used as biofuel in Indonesia.

\section{Soybean in Indonesia}

Soybean is one of the important legume crops in Indonesia, and becomes strategic commodity due to the volume of demand and a large and diverse usage. Soybean demand increases rapidly as the rate of population increase, which is about $1.8 \%$ per year (BPS 2012). Soybean is one of the strategic commodities in Indonesia, because it not only plays as a source of food, a source of nutrients, feed, and industrial raw materials, but also can be used as a fuel source. Diverse use of soybean in Indonesia led to domestic consumption continues to increase, so we need innovation that can provide high yielding varieties, but also in accordance with user preferences.

Soybean is not a native of Indonesia, but came from the sub-tropical regions. Some of soybean production centers countries are generally in sub-tropical regions like America. Tropical environment is not just ideal for soybean crops, but soybeans can be planted throughout the season. Sumarno \& Mansuri (2007) describe the environmental component which determines the soybean production: (1) climatic factors (temperature, sunlight, rainfall and rain distribution), (2) soil fertility and biology (texture, $\mathrm{pH}$, organic matter). Classified as short-day plant, soybean cannot be flowering when day length (long exposure) exceeds 16 hours and will be flowering faster when the irradiation less than 12 hours. In Indonesia, the range of day length are relatively similar between regions in Indonesia, this is in contrast to sub-tropical regions. Thus, the adaptation of soybean is the same relative to the day length.

In Indonesia, soybean cultivated on different agroecological, and cultivated in each growing season, depending on the soil type. In macro climate, the type of soybean agro ecology are the land type, planting season, cropping pattern and soil nutrients. A mix of types of land (upland and wetland) with the growing season led to the planting of soybean in Indonesia can be done in the rainy season, first dry season and second dry season (Krisnawati 2008). On upland, soybean cultivated at the beginning and end of the rainy season, while in wetland with sufficient irrigation, soybeans are in the cropping pattern of rice - rice - soybean. If irrigation water is limited, soybeans planted after rice. In both dry land and paddy fields, soybean always cultivated at the end of the growing season (Adie 2008). This is in differing with the soybean cropping pattern outside Java such that are on upland acid soil and tidal swamp area.

The local soybean production in Indonesia during the years 1992 to 2007 continued to decline with an average production of 6.26 percent per year. Soybean production in 1992 totaled 1.8 million tons, with harvested area of 1.6 million ha and a productivity of 1.12 t/ha. Until 2007 local soybean production continues to decline. Soybean production in 2007 only 592.534 ton with 459,116 ha area and productivity harvest $1.3 \mathrm{t} /$ ha. However, since the 2008-2009, local soybean production began to increase with the percentage of production each year by 30.91 percent and 24.59 percent. This increase was partly driven by the improvement in world soybean prices and a variety of government incentives for the achievement of selfsufficiency in soybeans in 2014 (Directorate General of Food Crops 2010).

Based on data from the Directorate General of Food Crops (2010), the area of soybean in Indonesia in 2009 was 722,931 ha. Soybean fields scattered across Indonesia, where the largest planting area for four years there are in the province of East Java, Central Java, West Nusa Tenggara, Aceh, Yogyakarta and West Java, with an area of each region of 231,992 ha, 104,976 ha, 76,905 ha, 32,513 ha, 31,347 ha, 28,680. Land outside Java is very promising, especially upland acid soil and tidal swamp land scattered outside Java has the potential for soybean farming. Areas outside Java has the potential to be planted soybeans are in NAD, West Sumatra, Jambi, South Sumatra, Lampung, Bali, South Sulawesi, Southeast Sulawesi and NTB.

In Indonesia, soybean mostly used as main raw material in the manufacture of tofu and tempeh. Soybean consumption in 2009 reached 2.3 million tons per year. From this amount, $50 \%$ is consumed in the form of soybean, $40 \%$ in the form of tofu, and $10 \%$ is other soy products such as soy sauce, bean curd, soy oil, etc (Ekasari 2009). This fact shows that soybean mostly used for processing industry and makes soybean as one of the important commodities in Indonesia. The soybean uses as source of biodiesel has not been done in Indonesia, but the research on extracted fat tofu to get soy oil as biodiesel feedstock has been done by Buchori et al. (2012). 


\section{Land Resources}

Indonesia is a tropical country which is potential as a producer of soybeans. Soybean not only as a food source but also as potential source for greening bioenergy. To optimize soybean as a source of bioenergy must consider the aspects of (1) competition with food crops, (2) increasing the competitive value, and (3) strengthening research and development support. Soybean bioenergy development must be carried outside of Java, either by utilizing the potential of existing land.

In general, soybeans can be grown on a variety of agro ecological, so soybean development program will provide considerable opportunities. The problem is how to eliminate the competition of land use for the benefit of food and bioenergy. Land resources in Java, in general has relatively fertile fertility rate, with no nutrient problems, but the land conversion is high enough for use on non-agricultural land use as well as the competition with other commodities (food, horticulture and plantation) also relatively very high. In contrast, land resources outside Java is quite extensive but constrained by soil nutrient problems and limited labour. Thus, the development of soy for biofuels is geared towards the existing land resources outside Java, performed under the monoculture and cultivated under annual crops.

The potential of Indonesian land resource is quite large. Theoretically, Indonesia has a land area reached 188.2 million ha, consisting of 148 million dry land and the rest of wetlands, including wetlands (peat, tidal and swampy) and paddy land that has become permanent.

The potential for acid dry land based on the land resourced data, about 148 million hectares of total dry land can be classified into 102.8 million ha of upland acidic soil area and 45.2 million ha is non-acid dry land (Mulyani et al. 2004). While in wetlands, acidic soil found in paddy fields derived from mineral materials which had further weathering on land and swamp land is mainly found in sulphuric acid and organic soil (peat). Swamp land in Indonesia covers approximately 33.4 to 39.4 million ha (Widjaja-Adhi et al. 2000), spread dominantly in Sumatra, Kalimantan, Sulawesi and Papua. The wetlands consist of tidal swamp land and 23.1 million ha of lowland swamp 13.3 million ha (Subagyo \& Widjaja-Adhi, 1998).

Table 1

Distribution of acid and swamp land in Indonesia

\begin{tabular}{crr}
\hline Island & $\begin{array}{c}\text { Acid land } \\
\text { (ha) }\end{array}$ & $\begin{array}{c}\text { Swamp land } \\
\text { (ha) }\end{array}$ \\
\hline Sumatera & $29,344,534$ & $9,390,000$ \\
Jawa & $3,807,011$ & - \\
Bali and Nusa Tenggara & 102,197 & - \\
Kalimantan & $39,242,486$ & $11,707,400$ \\
Sulawesi & $9,521,651$ & $1,793,450$ \\
Maluku & 3,539 & - \\
Papua & $17,259,511$ & $10,552,710$ \\
Indonesia & $102,817,113$ & $33,413,560$ \\
\hline
\end{tabular}

Nugroho et al. (1991) mapped the wetlands spread across four major islands (Table 1), namely Sumatra, Kalimantan, Sulawesi and Papua, with a total area of 33.4 million ha or $17 \%$ of the total land area of Indonesia (188.2 million ha). Wetlands are differentiated based on agro-ecosystems in relation to the hydrological system (water source), namely (1) tidal wetlands (tidal influenced) and (2) swampy wetlands (only influenced by rainfall). Tidal marsh plains land covers an area of 20.11 million ha, and the swampy marsh land area of 13.29 million ha. Tidal wetlands can be divided into potential land relative does not have a nutrient soil problem (2.07 million ha), acid sulphate soil (6.71 million ha), peat (10.89 million ha) and saline land (0.44 million ha). While the swampy wetlands consist of shallow swampy (4.17 million ha), mid valley (6.08 million ha), and in the lowland (3.04 million ha).

Facts on Table 1, shows that the vast majority of Indonesia's land, including land on acid land, most of which have been used to produce various kinds of agricultural products, both food crops and perennial crops (plantation and horticulture). Land of acidic soil widespread in Kalimantan and Sumatra, while for the largest swamps are in Kalimantan and Papua.

Utilization of the land resources for the development of soybean for biofuel innovation requires advanced support and efficient technology. It is based on soil nutrient constraints of acid soil land and marsh land. The main characteristic of acid land is a low level of productivity for soybeans, so it is necessary to increase the productivity by balanced fertilization (organic and inorganic fertilizers), and to raise the $\mathrm{pH}$ of the soil through calcification.

\section{Soybean as biofuel feedstock}

Based on statistical data, USA is the largest soybean producer country in the world. This is evidenced by the average number of U.S. soybean production over the last four years by 83 million tons or 35.75 percent of the total world production. Other countries are also the largest soybean producer country in the world including Brazil with an average production by 26.58 percent, 19.54 percent for Argentina, China at 6.35 percent and India by 3.8 percent, or the average number of individual production each country are 61.7 million tons, 45.4 million tons, 14.7 million tons, and 8.8 million tons, respectively (USDA 2010).

The volume of world soybean production for four years starting from 2006 to 2009 has fluctuated (Table 2). Based on the data in the world soybean consumption over the past four years have continued to rise. The high demand for soybeans is the case for a variety of benefits that can be derived from soybeans, 
Citation: Adie, M.M \& Krisnawati, A. (2014) Soybean Opportunity as Source of New Energy in Indonesia. Int. Journal of Renewable Energy Development, 3(1), 37-43 doi: 10.14710/ijred.3.1.37-43

$\mathrm{P}$ a g e $\mathbf{4 0}$

Table 2

The development of the world soybean production and demand in the period of 2006-2009

\begin{tabular}{cccc}
\hline Year & $\begin{array}{c}\text { Production } \\
\text { (million tons) }\end{array}$ & $\begin{array}{c}\text { Consumption } \\
\text { (million tons) }\end{array}$ & $\begin{array}{c}\text { Deficit } \\
\text { (million } \\
\text { tons) }\end{array}$ \\
\hline 2006 & 237 & 225 & 12 \\
2007 & 221 & 230 & -9 \\
2008 & 211 & 220 & -9 \\
2009 & 250 & 234 & 16 \\
\hline
\end{tabular}

both to meet the needs of food and non-food needs. For the needs for food, vegetable protein contained in soybean is quite large and good for health. In some countries such as Indonesia, soybeans consumed in various types of snacks and widely used as a source of vegetable protein which is relatively cheaper when compared with that of the animal protein meat. While in the non-food sector, soybean is widely used as an alternative energy sources (biofuels) (USDA 2010).

Biofuels have increased in popularity because of the rising oil prices and need for energy security. Many countries around the world have used and produced biofuels, such as biodiesel, as an alternative energy source to fossil fuels and oil. Developing renewable fuels is desirable because they are derived from sustainable sources of energy, whereas petroleum fuels come from a finite resource that is rapidly being depleted (Pradhan et al. 2009).

The United Soybean Board terms biodiesel as a mono-alkyl oxygenated fuel made from soybean or other vegetable oils or animal fats. Soybean oil is the only part of the soybean used in biodiesel. This means that the solids can continue to be used for animal and human protein consumption and remain completely unused by the biodiesel process. Currently, 14 percent of the soybean oil consumption goes to biodiesel (USB 2009).

Biodiesel is a fuel made mostly from crops with seeds that contain oil. Biodiesel fuel is processed and refined from raw materials with high oil content. Biodiesel can be mixed with petroleum diesel at any concentration in most modern diesel engines. Oilseed crops in the U.S. include soybeans and canola, but soybean is the primary feedstock used for biodiesel production (Sheehan et al. 1998). In Europe the most common Biomass crops grown for conversion into biofuels are rapeseed, flax seed, sugar beet, wheat, soybeans and corn (USB 2009). In tropical regions, promising oilseed crops are soybean, palm and jatropha (Anonim 2013).

Sources of soy biodiesel are soybean oil and straw (Kis et al. 2009). Soybean oil, derived from the seed of the legume plant Glycine max, is currently a major feedstock for the production of biodiesel. Recent years, research has been carried out using soybean oil as a fuel. But until now the use of soybean oil for fuel is still influenced by the need for food and feed soybeans are still not fulfilled. In addition, the processing price is still higher than the price of oil. While there are sources of fuel material from other plants, but most plants take nutrients are very high. So the 3rd year and beyond will be a decrease in productivity. This is in contrast to soybean plants that actually makes a fertile soil, so that the continuity of production is maintained.

Oil extraction from soybeans and biodiesel production can be performed using conventional and ultra-sonication methods (Koc et al. 2011). Soybean biodiesel production is divided into five distinct processes: (1) soybean production (or farm inputs), (2) transport of soybeans to the processing facility, (3) separation of oil and meal, (4) conversion into biodiesel (or transesterification), and (5) transportation of biodiesel for distribution (Sheehan et al. 1998). Biodiesel derived from soybeans is sometimes called soydiesel, methyl soyate or soy methyl esters (SME) (Sadaka 2008).

Compared with other biodiesel feedstock crops, soybeans contain approximately 18 to $20 \%$ oil compared to other oilseed crops such as canola (40\%) and sunflower (43\%) (Berglund et al. 2008). With a yield of oil of $18 \%$ then $5,556 \mathrm{~kg}$ of soybeans are required to produce $1,000 \mathrm{~kg}$ of oil (Pimentel \& Patzek 2005). Although soybeans contain less oil than sunflower, soybeans can be produced without or nearly zero nitrogen. This makes soybeans advantageous for the production of biodiesel (Pimentel 1998).

Food and Agriculture Organization of the United Nation (FAO 2009) stated many environmental problems associated with large scale production of soybeans and maize, but Life Cycle Assessment (LCA) studies indicated that cultivation of soybeans has less negative impacts on environment than some other oil seeds like sunflower and rapeseed (Sanz Requena et al. 2011). Another report from Pimentel \& Patzek (2005) stated that the energy output from biodiesel is less than the fossil energy inputs. They claimed that the fuel produced using soybean oil required $27 \%$ more fossil energy than the energy contained in the biodiesel. But this result has created much controversy, because there was some different with research by other researchers. For example, Jobe \& Duffield (2005) questioned the validity of Pimentel and Patzek's data on agricultural energy input and energy requirements for secondary inputs, such as steel and cement. Morris (2005) also pointed out some of the weaknesses in Pimentel and Patzek's analysis, noting that (1) the study was not clear about the inclusion of energy used to modify the vegetable oil into an ester suitable for use as a diesel fuel, (2) energy appropriated to the soy meal was only about $15 \%$ of the total input, and (3) Pimentel and Patzek assumed lime use of 2.2 tons per acre of soybean per year, ignoring the fact that one application can last for up to 10 years. However, the contradictory results were mainly due to differences in the proportion of energy allocated to biodiesel and its meal 
coproduct. All models except Pimentel reported a positive NER (Pradhan et al. 2008). NER (net energy ratio) is defined as the total energy produced by the system divided by the total energy consumed by the system (Spath \& Mann 2000).

Soybean biodiesel is claimed to be better for the environment because it is made from renewable resources and has lower emissions compared to petroleum diesel. It also produces more usable energy and reduces greenhouse gases more than corn-based ethanol, making it more deserving of subsidies. Studies have shown that biodiesel from virgin vegetable oil reduces carbon dioxide emissions and petroleum consumption when used in place of petroleum diesel. In addition, the use of biodiesel reduces $\mathrm{CO}_{2}$ in the earth's atmosphere. This is due to the fact that growing soybeans consumes nearly four times as much $\mathrm{CO}_{2}$ as the amount of $\mathrm{CO}_{2}$ produced from biodiesel exhaust (Anonim 2013).

\section{Soybean current potential for biofuel in Indonesia}

Within a number of developed countries and industrialized countries, the use of biodiesel derived from industrial plants has become more prevalent. Soybean is one of them which is quite much required by industrial manufacture of biofuels. This means there will be competition on the demand side to get the soybeans to be processed for the manufacture of processed foods or making biodiesel (Arifin 2008). However, growing soybeans for fuel is a value added opportunity for soybean farmers. As the demand for soy biodiesel increases, the need for soybean production and processing will also increase.

Currently, there are many countries which produce and use biofuels commercially from domestic vegetable material. Germany, France and Austria using canola (rapeseed), Spain relies on olive oil, the United States in soybean oil and corn, and Italy in sunflower. Development of biofuels has also been carried out by developing countries. Mali, India and Africa develop jatropha (Jatropha oil), Philippine Coconut (cocodiesel), Brazilian in sugarcane, and Malaysia in palm oil. Currently, Indonesia is developing biofuel from palm oil and jatropha for biodiesel substitution (Hendroko 2008). However, soybean also has a good prospects to become an alternative energy in Indonesia. Soybean as human food can be known from its role as an essential ingredient commodities in nine basic needs of the people of Indonesia. In addition, besides popular as a healthy food, soybean likely to be developed into alternative energy be based on the availability of land and varieties.

If it is related with availability of land for soybean production as a source of biodiesel, there are still millions of acres of land that could potentially be exploited for soybean planting. In 2010, there were more than 30 provinces have registered to soybean cultivation and production nationally. Soybean crop requires upland area that are found in almost all regions of the province in Indonesia. But the potential of land to be developed is land that is outside of Java, including: acid soil, swamp land, lowland, and tidal land. Swamp land in Indonesia is 33.4 million hectares, consisting of 20,192 million hectares of tidal and 13,283 million hectares of lowland. For example, the Kalimantan Island has the potential to be a soybean field that can reach over 3 million hectares (Alihamsyah et al. 2003).

In terms of the varieties, it began with soybean (Glycine max (L.) Merrill) breeding activities in Indonesia that have lasted very long, as well as the history of the soybean crop that entered into Indonesia on the eve of the 17th century. Soybean cultivation began to be cultivated in 1853, and in 1935 have been planted around the island of Java. The first Indonesian soybean varieties, Otau, was released in 1918. In the period 1918 to 2012, the Indonesian government has released as many as 72 soybean varieties (Balitkabi 2012). Soybean varieties in Indonesia obtained through crossbreeding (37 varieties), foreign or introduction (18 varieties), local variety (11 varieties) and irradiation (6 varieties). Genetic improvement of agronomic traits, especially for seed yield, continue to be carried from year to year. Soybean seed yield from the start of the release up to 2008, shows increase potential yield that tend to be linear. It is suggest that a genetic approach has been successful in increasing yield potential of soybean varieties in Indonesia (Krisnawati \& Adie 2009).

Indonesian Agency for Agricultural Research and Development (IAARD) has released 73 soybean varieties, which are 19 varieties have the potential production between 2.16 to 3.50 t/ha (Balitkabi 2012). From a total of 73 releasing soybean varieties, the average of oil content is $18 \%$. Black soybean variety of Detam-1 has the highest oil content, ie $33.06 \%$. In terms of high yield and oil content, other soybean varieties that can potentially be used as a feedstock for biodiesel are Argopuro, Argomulyo, Burangrang, Grobogan, Mitani, and Mallika (Table 3).

Black soybean varieties of Detam-1 is able to produce up to $3.45 \mathrm{t} / \mathrm{ha}$, and has a large seed size as

Table 3

Indonesian soybean varieties with high oil content and high seed yielding for biodiesel

\begin{tabular}{llccl}
\hline No & $\begin{array}{c}\text { Soybean } \\
\text { variety }\end{array}$ & Oil (\%) & $\begin{array}{c}\text { Average seed } \\
\text { yield (t/ha) }\end{array}$ & Origin \\
\hline 1 & Detam-1 & 33.06 & 2.51 & Crossing \\
2 & Argopuro & 25.10 & 2.31 & Introduction \\
3 & Argomulyo & 20.80 & 1.75 & Introduction \\
4 & Burangrang & 20.00 & 2.05 & Selection \\
5 & Grobogan & 18.40 & 2.77 & Crossing \\
6 & Mitani & 20.48 & 2.00 & Irradiation \\
7 & Mallika & 20.00 & 2.34 & Selection \\
\hline
\end{tabular}


Citation: Adie, M.M \& Krisnawati, A. (2014) Soybean Opportunity as Source of New Energy in Indonesia. Int. Journal of Renewable Energy Development, 3(1), 37-43 doi: 10.14710/ijred.3.1.37-43

$\mathrm{P}$ a g e $\mathbf{4 2}$

seed weighs $14.84 \mathrm{~g} / 100$ seeds. In addition to having a higher oil content (33.06\%), is also the first black soybean varieties in Indonesia that large seed size as well as the highest protein (45.36\% dry basis). Another black soybean variety is Mallika with broad adaptation. Varieties Burangrang has $20 \%$ oil content, and high yielding variety of Grobogan has $18.40 \%$ oil with a good adaptation in some different environmental conditions, in the rainy season and in the area with a good irrigation system. Varieties of Argopuro and Argomulyo were from introduction, but have a high oil content $25.10 \%$ and $20.8 \%$, respectively. Variety of Mitani (20.48\% oil) adapted to upland. These varieties are prospective to be developed as source of biodiesel. Another soybean chemical properties that need to be notified is the linolenic acid. Linolenic acid is the polyunsaturated fatty acid most responsible for making soybean oil prone to rapid spoiling, prompting the use of partial hydrogenation to increase stability and shelf life. Soybean cultivars with low linolenic acid content for biodiesel production will improve its oxidative stability and the cold filter plugging point (CFPP) (Santos et al. 2013). Hence, all the prospective soybean varieties are also needed to be determined its linolenic acid.

\section{Soybean competition for bioenergy and food security}

Bioenergy and food security are closely linked at several levels. Bioenergy development may affecting four dimensions of food security: availability, access, utilization, and stability (FAO 2012). The expansion of biofuels can have two primary effects on food security. On the one hand, direct effects may occur through this tendency for industrial-scale feedstock production to displace customary land uses. On the other hand, the effects of these land use changes and diverted end uses of multi-purpose feedstock on food prices can undermine food access by the poor (German et al. 2011).

In Brazil, it is reported that the demand for soybeans to make biodiesel competes with the demand for food uses (mainly cooking oil). It also indicates that the changed land use dynamic from agro-energy has been generating effects from the substitution of crops, away from soybeans in Parana and from oranges in the state of Sao Paulo. These changes have triggered secondorder effects, particularly an increase of around 160$170 \%$ in the price per hectare of agricultural land in Sao Paulo (Benedetti et al. 2007).

In Indonesia, the uses soybean as a source of bioenergy facing problems of land area competition and insufficient production. Since soybean can be planted in various agro-ecological area, soybean yield can be increase by utilizing the land area outside Java through
Table 4.

Soybean area and biodiesel potential production according by region in Indonesia.

\begin{tabular}{lcc}
\hline \multicolumn{1}{c}{ Area } & $\begin{array}{c}\text { Soybean area } \\
\text { (ha) }\end{array}$ & $\begin{array}{c}\text { Biodiesel } \\
\text { (kl) }\end{array}$ \\
\hline Sumatera & 67,201 & 302,404 \\
Java & 588,234 & $2,647,052$ \\
Bali and West Nusa Tenggara & 123,594 & 556,171 \\
Kalimantan & 10,988 & 49,445 \\
Sulawesi & 41,761 & 187,924 \\
$\quad$ Maluku and Papua & 247,832 & $1,115,245$ \\
\hline Note: each hectare of soybean plantation be able to produce biodiesel \\
$\quad$ an average of 4.5 kl. \\
Source: BPS (2004)
\end{tabular}

intercropping or planting under annual crops using adapted cultivar, and through improved agricultural methods.

The biggest land competition soybean for bioenergy and for food uses is in Java Island. To eliminate the competition, soybean is potential to be developed in existing land resources outside Java (Table 4). The strategy on the development soybean for bioenergy outside Java are with utilization of arable land which is suitable for soybean, opening new land and development of soybean under annual crops.

Challenges within the use of soy as biofuels is a low of national soybean production, so that in addition to need to increase soybean yields, also required land preparation, technology and human resources, so that the use of soy as an alternative energy source to oil is more optimal, efficient, and powerful.

\section{Conclusion}

Soybeans contain approximately 18 to $20 \%$ oil that can be produced without or nearly zero nitrogen, and claimed to be better for the environment, so that makes soybeans advantageous for the production of biodiesel. Soybean crop development opportunities as biodiesel in Indonesia is very large, in terms of land availability and varieties. There are seven varieties of high yielding soybean and has a high oil content that could be used as source of soy biodiesel. Varieties with the most potential as a renewable energy source are Detam-1 and Argopuro. Challenge for the future is to increase the national soybean production, technology and human resources development, as well as further research on soy biofuel.

\section{References}

Adie, M.M. (2008) Budidaya Kedelai dan Karakteristik Tanaman Kedelai Berkaitan dengan Waktu Tanam. Pelatihan Prosesing Benih Kedelai bagi Penangkar. Balai Pendidikan dan Pelatihan Pertanian. Nganjuk.

Alihamsyah, Sarwani, T.M., Jumberi, A., Ar-Riza, I., Noor, I. \& Sutikno, H. (2003) Lahan Pasang Surut: Pendukung Ketahanan Pangan dan Sumber Pertumbuhan Agribisnis. Balai Penelitian Pertanian Lahan Rawa. Banjarbaru.

Anonim. (2013) Facts about biofuels: Biodiesel. Energy Future Coalition, United Nations Foundation. Available from, 
http://www.energyfuturecoalition.org/biofuels/fact_biodiesel.ht $\mathrm{m}$ Accessed date 2 June 2013.

Arifin, B. (2009) Mengantisipasi Krisis Pangan Lebih Dasyat. Majalah GATRA, Kolom, 9 April 2008. Available from, http://barifin.wordpress.com/2012/11/19/mengantisipasikrisis-pangan-lebih-dahsyat/ Accessed date 10 June 2013.

Balitkabi (Balai Penelitian Tanaman Kacang-kacangan dan Umbiumbian). (2012) Deskripsi Varietas Unggul Kacang-kacangan dan Umbi-umbian. Malang.

Benedetti O.I.B, Rathmann, R., Padula, A.D. \& Steinhorst, G.P. (2007) Usage competition between oilseeds and biofuels: impact assessment on the Brazilian food production. In: 17th annual world food and agribusiness forum and symposium - IFAMA, Parma.

Berglund D.R., McKay, K., \& Knodel, J. (2007) Canola Production, North Dakota State University, A-686 revised August 2007

BPS. (2012) Tabel Luas Panen- Produktivitas- Produksi Tanaman Kedelai Seluruh Provinsi. Availble from, http://www.bps.go.id/tnmn_pgn.php?adodb_next_page $=1$ \&eng $=0$ \&pgn=3\&prov=99\&thn $1=2007 \&$ thn $2=2012 \&$ luas=1 1 \&produktivit as=1\&produksi=1 Accessed date 19 June 2013

BPS. (2004) Statistik Perkebunan Kelapa Sawit. Ditjen Bina Produksi Perkebunan. Buku Statistik Indonesia.

Buchori, L., Sasongko, S.B., Anggoro, D.D. \& Aryanti, N. (2012) Pengambilan Minyak Kedelai dari Ampas Tahu sebagai Bahan Baku Pembuatan Biodiesel. J. Ilmu Lingkungan 10 (2), 49-53.

Directorate General of Food Crops. (2010) Pedoman Pelaksanaan Sekolah Lapangan Pengelolaan Tanaman Terpadu (SL-PTT) Tahun 2010. Direktorat Jenderal Tanaman PAngan, Kementrian Pertanian.

Ditjentan. (2004) Profil Kedelai. Ed ke-1. Direktorat Kacang-kacangan dan Umbi-umbian .Jakarta: Kementrian Pertanian.

Ekasari, Y. (2009) Pengaruh Lama Fermentasi Rhizopus Oligosporus Terhadap Kadar Oligosakarida dan Sifat Sensorik Tepung Tempe Kedelai, Laporan Tugas Akhir, Program Studi S1 gizi, Fakultas Ilmu Kesehatan, Universitas Muhammadiyah Surakarta.

FAO. (2009) The State of Food and Agriculture 2009, FAO. Rome, Italy.

German, L., G. C. Schoneveld, \& P. Pacheco (20110 The social and environmental impacts of biofuel feedstock cultivation: evidence from multi-site research in the forest frontier. Ecology and Society 16(3), 24.

Hendroko, R. 2008. Energi Hijau: Pilihan Bijak Menuju Negeri Energi Mandiri. Niaga Swadaya.

Jobe, J., \& Duffield, J. (2005) NBB and USDA statements on Pimentel energy balance paper. Jefferson City, Mo.: National Biodiesel Board.

Kis, D., Sucic, B., Guberac, V., Voca, N., Rozman, V. \& Sumanovac, L. (2009) Soybean Biomass as A Renewable Energy Resources. Agriculture Conspectus Scientificus 74 (3), 201-203.

Koc, A.B., Abdullah, A. \& Fereidouni, M. (2011) Soybeans Processing for Biodiesel Production, Soybean - Applications and Technology, Prof. Tzi-Bun Ng (Ed.), ISBN: 978-953-307-207-4, InTech, Available from, http://www.intechopen.com/books/soybeanapplications-andtechnology/soybeans-processing-for-biodieselproduction Accessed date 2 June 2013.

Krisnawati, A \& Adie, M.M. (2008) Ragam umur masak plasma nutfah kedelai dan kontribusinya terhadap hasil. Agritek 17 (11), 25-29.

Krisnawati, A. (2008). Pengenalan dan Wilayah Adaptasi Varietas Unggul Kedelai. Pelatihan Prosesing Benih Kedelai bagi Penangkar. Balai Pendidikan dan Pelatihan Pertanian. Nganjuk, 8 Juli 2008.

Mulyani, A., Hikmatullah, \& Subagyo, H. (2004) Karakteristik dan potensi tanah masam lahan kering di Indonesia. hlm. 1-32 in Prosiding Simposium Nasional Pendayagunaan Tanah Masam. Pusat Penelitian dan Pengembangan Tanah dan Agroklimat, Bogor.

Morris, D. (2005) The carbohydrate economy, biofuels and the net energy debate. Minneapolis, Minn.: Institute for Local Self-Reliance. Available from, www.newrules.org/agri/netenergyresponse.pdf. Accessed date 2 June 2013.

Nugroho, K., Alkasuma, Paidi, Wahdini, W., Abdulrachman, Suhardjo, H., \& Widjaja-Adhi, I P.G. (1991) Laporan Akhir. Penentuan Areal
Potensial Lahan Pasang Surut, Rawa, dan Pantai skala 1:500.000. Laporan Teknik No. 1/PSRP/1991. Proyek penelitian Sumber daya Lahan, Puslittanah dan Agroklimat, Bogor.

Pimentel, D. (1998) Energy and Dollar Costs of Ethanol Production with Corn: Hubbert Center Newsletter \#98/2, M. King Hubbert Center for Petroleum Supply Studies, Colorado Sch. Mines. Golden, CO.

Pimentel, D. \& Patzek, T. (2005) Ethanol Production Using Corn, Switchgrass, and Wood; Biodiesel Production Using Soybean and Sunflower. Natural Resources Research, 14 (1), 65-76.

Pradhan, A., Shrestha, D.S., Van Gerpen, J. \& Duffield, J.A. (2008) The Energy Balance of Soybean Oil Biodiesel Production: A Review of Past Studies. Trans. ASABE 51(1): 185-194.

Pradhan, A., Shrestha, D.S., McAloon, A., Yee, W., Haas, M., Duffield, J.A. \& Shapouri. H. (2009) Energy Life-Cycle Assessment of Soybean Biodiesel. Agricultural Economic Report No. 845. Washington, D.C.: USDA, Office of the Chief Economist, Office of Energy Policy and New Uses. Available from, www.usda.gov/oce/reports/energy/ELCAofSoybeanBiodiesel914 09.pdf. Accessed date 15 December 2010. Accessed date 2 June 2013.

Sadaka, S. (2008) Biodiesel. Agriculture and Natural Resources, Cooperative and Extension Service, University of Arkansas.

Santos, E.M., Piovesan, N.D., de Barros, E.G. \& Morreira, M.A. (2013) Low Linolenic Soybeans for Biodiesel: Characteristics, Performance and Advantages. Fuel, 104, 861-864.

Sanz Requena, J.F., Guimaraes, A.C., Quirós Alpera, S., Relea Gangas, E., Hernandez-Navarro, S., Navas Gracia, L.M., Martin-Gil, J. \& Cuesta, F.H. (2011) Life Cycle Assessment (LCA) of the biofuel production process from sunflower oil, rapeseed oil and soybean oil. Fuel Processing Technology 92 (2), 190-199.

Sheehan, J., Camobreco, V., Duffield, J.A., Graboski, M. \& Shapouri. H. (1998) Life-cycle Inventory of Biodiesel and Petroleum Diesel for Use in an Urban Bus. A Joint Study Sponsored by U.S. Department of Agriculture and U.S. Department of Energy. NREL/SR-58024089 Golden, CO: National Renewable Energy Laboratory. U.S. Department of Energy, 5/1998.

Singh, S.P. \& Singh, D. (2010) Biodiesel production through the use of different sources and characterization of oils and their esters as the substitute of diesel: A review. Renewable and Sustainable Energy Reviews, 14(1), 200-216.

Spath, P. L., \& Mann, M. K. (2000) Life cycle assessment of a natural gas combined-cycle power generation system. NREL/TP-570-27715. Golden, Colo.: National Renewable Energy Laboratory. Accessed date 10 June 2013.

Subagyo, H. \& Widjaja-Adhi, I PG. (1998) Peluang dan kendala pembangunan lahan rawa untuk pengembangan pertanian di Indonesia. hlm. 13-50 In Prosiding Pertemuan Pembahasan dan Komunikasi Hasil Penelitian Tanah dan Agroklimat: Makalah Utama. Bogor, 10-12 Februari 1998. Pusat Penelitian Tanah dan Agroklimat, Bogor.

Sudaryanto, T. \& Swastika, D.K.S. (2007) Ekonomi Kedelai di Indonesia. Badan Penelitian dan Pengembangan Pertanian. Pusat Penelitian dan Pengembangan Tanaman Pangan. Bogor.

Sumarno \& Manshuri, A.G. (2007) Persyaratan Tumbuh dan Wilayah Produksi Kedelai di Indonesia. Badan Penelitian dan Pengembangan Pertanian. Pusat Penelitian dan Pengembangan Tanaman Pangan. Bogor.

USB (United Soybean Board). (2009). Soybean Oil Consumption 2007/2008. United Soybean Board Market View Database. Available from, http://usb.adayana.com:8080/usb/jsp/login.jsp

USDA (U.S. Department of Agriculture). (2010) World Soybean Production, Consumption, Area, and Yield. Available from, http://www.earth-policy.org/data_center/C24.

Widjaja-Adhi, I P.G., Suriadikarta, D.A., Sutriadi, M.T., Subiksa, I G.M. \& Suastika, I.W. (2000) Pengelolaan pemanfaatan dan pengembangan lahan rawa. hlm. 127-164 In Buku Sumber Daya Lahan Indonesia dan Pengelolaannya. Pusat Penelitian Tanah dan Agroklimat, Bogor. 